\title{
Glucagon-stimulable Adenylyl Cyclase in Rat Liver \\ Effects of Chronic Uremia and Intermittent Glucagon Administration
}

Rajan R. Dighe, Francisco J. Rojas, Lutz Birnbaumer, and Alan J. Garber

Departments of Medicine, Cell Biology, and Biochemistry, Baylor College of Medicine and The Methodist Hospital, Houston, Texas 77030

bstract. The effects of chronic uremia and glucagon administration on glucagon-stimulable adenylyl cyclase in rat liver were assessed by determinations of adenylyl cyclase activities, specific iodoglucagon binding, and the activity of the stimulatory regulatory component of adenylyl cyclase. Glucagon-stimulated adenylyl cyclase was reduced in uremia to $75-80 \%$ of control levels $(P$ $<0.05$ ), in the presence or absence of saturating levels of guanosine triphosphate (GTP) and 5'-guanylylimidodiphosphate [GMP-P(NH)P]. Although these changes were accompanied by a concomitant $20 \%$ reduction in sodium fluoride-stimulated activity, basal, GTP-, GMP$\mathrm{P}(\mathrm{NH}) \mathrm{P}-$, and manganese-dependent adenylyl cyclase activities were unchanged. Using $\left[{ }^{125} \mathrm{I}-\mathrm{Tyr}^{10}\right]$ monoiodoglucagon as a receptor probe, the number of high affinity glucagon-binding sites was reduced $28 \%(P<0.01)$ in uremic as compared with control liver membranes. However, the affinity of these binding sites was unaltered. The S49 $c y c^{-}$-reconstituting activity with respect to both GMP-P(NH)P- and isoproterenol plus GTP-stimulable adenylyl cyclase was unaltered in membranes from uremic as compared with control rats. Intermittent glucagon (80$100 \mu \mathrm{g}$ ) injections administered at 8-h intervals to normal rats reproduced all of the above described effects of chronic experimental uremia on the adenylyl cyclase system. It is concluded that changes in the hormone-stimulable ad-

Address all reprint requests to Dr. Garber.

Received for publication 22 December 1982 and in revised form 29 December 1983.

J. Clin. Invest

(C) The American Society for Clinical Investigation, Inc. 0021-9738/84/04/1004/09\$1.00

Volume 73, April 1984, 1004-1012 enylyl cyclase complex in uremia and with glucagon treatment result primarily from a decrease in the number of hormone-specific receptor sites in hepatic plasma membranes. Since the changes in liver adenylyl cyclase are qualitatively and quantitatively the same in glucagontreated and uremic rats, it is suggested that these may be the result of the hyperglucagonemia of uremia. Further, the data reveal an unexpected dissociation between guanine nucleotide and sodium fluoride stimulation of adenylyl cyclase. Possible causes for this dissociation based on the known subunit composition of cyclase coupling proteins are discussed.

\section{Introduction}

Abnormal carbohydrate metabolism is a frequent concomitant of chronic renal disease (1-3). As the result, in part, of the diminished renal clearance of glucagon, hyperglucagonemia is frequently observed in renal insufficiency $(4,5)$. These increased immunoreactive glucagon levels result from increases in a number of molecular weight species, each of which may have glucagon-like immunoreactivity if not biological activity (6-8). Glucagon-stimulable adenylyl cyclase activity in liver of uremic rats has been found to be increased $(9,10)$. Other more indirect assessments have inferred a decreased activity of this enzyme in chronic uremia (11). In light of these discordant data and to determine the impact of the uremic state on the hormone-stimulable adenylyl cyclase complex, we have used a monoiodinated glucagon as a probe of glucagon receptor density and affinity in membrane preparations of rat liver (12), and have now developed and validated reconstitution assays using $\mathrm{S} 49 \mathrm{cyc}^{-}$lymphoma cell membranes to measure the activity of the stimulatory regulatory component which links the glucagon receptor to the catalytic component of adenylyl cyclase. The effects of chronic uremia have been compared with the effects of intermittent glucagon administration in vivo on these parameters in rat liver. The implications of these findings for the regulation of hormonestimulable adenylyl cyclase activities are discussed. 


\section{Methods}

Myokinase, creatine phosphokinase, creatine phosphate, ATP, cAMP, guanosine triphosphate (GTP) ${ }^{1}$, DNAse I, isoproterenol, and other biochemical reagents were obtained from Sigma Chemical Co. (St. Louis, MO). Cholic acid was also purchased from Sigma Chemical Co. and recrystallized from ethanol six times before using. [ $\left.\alpha{ }^{32} \mathrm{P}\right] \mathrm{ATP}(\sim 25 \mathrm{Ci} /$ $\mathrm{mmol}$ ) was either purchased from the International Chemical and Nuclear Corp. (Irvine, CA) or supplied by the Molecular Endocrinology Core Laboratory of the Baylor Center for Diabetes and Endocrinology Research. $\left[{ }^{3} \mathrm{H}\right] \mathrm{cAMP}(\sim 21 \mathrm{Ci} / \mathrm{mmol} \mathrm{sp}$ act $)$ was purchased from Amersham Corp. (Arlington Heights, IL). 5' Guanylylimidodiphosphate [GMPP(NH)P] was purchased from Boehringer Mannheim Biochemicals (Indianapolis, IN). DEAE-Sephadex was purchased from Pharmacia Fine Chemicals (Piscataway, NJ). Glucagon injected into animals was purchased from Sigma Chemical Co. or Eli Lilly \& Co. (Indianapolis, IN). Glucagon used in adenylyl cyclase assays and for iodination was a generous gift of Dr. W. W. Broomer (Eli Lilly \& Co.). [ $\left.{ }^{125} \mathrm{I}-\mathrm{Tyr}^{10}\right]-$ monoiodoglucagon, prepared by iodination of native glucagon with carrier-free sodium [ ${ }^{125}$ I]iodide in the presence of Iodogen followed by high pressure liquid chromatography purification using a $\mu$ Bondapak $C_{18}$ column described by Rojas et al. (12), was supplied by the Molecular Core Laboratory of the Baylor Diabetes and Endocrinology Research Center.

Female Sprague-Dawley rats (150-200 g) from TIMCO (Houston, TX) were used in these studies. Animals were made uremic by unilateral nephrectomy and ligation of two branches of the contralateral renal artery as described previously $(13,14)$. The animals were maintained on a high-protein diet and then sacrificed by decapitation after $7 \mathrm{~d}$. Blood-urea nitrogen (as milligrams per 100 milliliters whole blood) was $57 \pm 4$ (mean \pm SE) in the uremic group and $14 \pm 2$ in the control group. Glucagon-treated animals were prepared as described in Results.

\section{Membrane preparations}

The livers from uremic, normal, or glucagon-treated rats were quickly removed, placed on ice, and the membranes prepared according to the procedure of Neville (15) as modified by Pohl et al. (16). The membranes were then stored at $-80^{\circ} \mathrm{C}$. Cyc murine lymphoma $\$ 49$ cells were grown and membranes (cyc- membranes) prepared by Dr. Ravi Iyengar (Department of Cell Biology, Baylor College of Medicine) using procedures described elsewhere $(17,18)$.

\section{Adenylyl cyclase assays}

Liver membranes (8-12 $\mu \mathrm{g}$ protein) were incubated for $10 \mathrm{~min}$ at $30^{\circ} \mathrm{C}$ in a final volume of $50 \mu$ containing $0.1 \mathrm{mM}\left[\alpha-{ }^{32} \mathrm{P}\right] \mathrm{ATP}(1,000-1,500$ cpm/pmol), $5 \mathrm{mM} \mathrm{MgCl}$, $1 \mathrm{mM}$ EDTA, $\left.1 \mathrm{mM}{ }^{3} \mathrm{H}\right] \operatorname{cAMP}(\sim 10,000$ cpm), $25 \mathrm{mM}$ Tris- $\mathrm{HCl}$, the indicated additives, and an ATP-regenerating system consisting of $0.02 \mathrm{mg} / \mathrm{ml}$ myokinase, $0.2 \mathrm{mg} / \mathrm{ml}$ creatine phosphokinase, and $20 \mathrm{mM}$ creatine phosphate. The incubations were terminated by the addition of $100 \mu \mathrm{l}$ of a stop solution consisting of 40 mM ATP, $10 \mathrm{mM}$ of cAMP, and $1 \%$ sodium dodecyl sulfate. $\left[{ }^{32} \mathrm{P}\right] \mathrm{cAMP}$ formed was quantitated by the method of Salomon et al. (19) as modified by Bockaert et al. (20). Both the ATP and the reagents used to regenerate it during the assays were purified from contaminating "GTP-like" materials as described elsewhere $(21,22)$.

1. Abbreviations used in this paper: GMP-P(NH)P, $5^{\prime}$ guanylylimidodiphosphate; GTP, guanosine triphosphate.

\section{Glucagon-binding assays}

Membranes (2-5 $\mu \mathrm{g}$ protein) were incubated for $20 \mathrm{~min}$ at $32.5^{\circ} \mathrm{C}$ in a final volume of $100 \mu \mathrm{l}$ of a medium containing varying concentrations of [ $\left.{ }^{125} \mathrm{I}\right]$ monoiodoglucagon $(0.20-3.0 \mathrm{nM}), 25 \mathrm{mM}$ Tris- $\mathrm{HCl}, \mathrm{pH} 7.5$, $1.0 \mathrm{mM}$ EDTA, $0.1 \%$ bovine serum albumin (BSA), and other additions as indicated. At the end of the incubation, the reaction mixtures were diluted with $5 \mathrm{ml}$ of ice-cold $25 \mathrm{mM}$ Tris- $\mathrm{HCl}$, pH 7.5, and $0.1 \%$ BSA (buffer), and filtered rapidly through $0.45-\mu \mathrm{M}$ cellulose acetate filters (Nuflow Oxoid, Columbia, MD) that had been presoaked overnight in $10 \%$ BSA. The tubes were rinsed once with $5 \mathrm{ml}$ of ice-cold buffer and the rinse filtered through the Oxoid filters, which were then immediately washed with a final 5-ml aliquot of the ice-cold buffer. The filters were counted in a Searle Analytical gamma counter at a counting efficiency of $50 \%$. To determine the nonspecific binding, membranes were incubated under identical conditions with [ $\left.{ }^{125} \mathrm{I}\right]$ iodoglucagon in the presence of $3.0 \mu \mathrm{M}$ unlabeled glucagon. Specific binding was determined by subtracting nonspecific bound counts from the total bound counts. The data obtained were analyzed according to Scatchard (23) to determine both the dissociation constant $\left(K_{\mathrm{D}}\right)$ and the number of specific binding sites on the membranes tested.

\section{Measurement of regulatory component activity of liver membranes by cholate extraction and reconstitution into $\mathrm{cyc}^{-}$membranes}

Extraction of regulatory component activity and selective inactivation of coextracted catalytically active adenylyl cyclase activity. Membranes were mixed with extraction medium to give a final concentration of $1 \%$ cholate, $25 \mathrm{mM}$ Na-HEPES, pH 8.0, $1.0 \mathrm{mM}$ EDTA, and $10 \mathrm{mM}$ $\mathrm{MgCl}_{2}$. Membrane concentration during extraction was $5-7.5 \mathrm{mg} / \mathrm{ml}$. The membrane-cholate mixtures thus obtained were kept on ice for 60 min with occasional stirring. The EDTA concentration was increased to $10 \mathrm{mM}$ to chelate excess $\mathrm{MgCl}_{2}$ and the mixtures centrifuged in the cold at $100,000 \mathrm{~g}$ for $60 \mathrm{~min}$. The supernatants were then warmed at $30^{\circ} \mathrm{C}$ for 5 min yielding the cholate extracts in which regulatory component activity was measured by reconstitution of GMP-P(NH)P or isoproterenol plus GTP-stimulated adenylyl cyclase activities in $c y c^{-}$ membranes. As shown under Results, the above procedure results in a recovery of $\sim 75 \%$ of the total regulatory component activity measurable in the membrane-cholate mixtures.

Reconstitution of GMP-P(NH)P-stimulated activity in $\mathrm{cyc}^{-}$membranes. Cholate extracts were diluted 25 -fold or more with dilution medium consisting of $1.5 \mathrm{M} \mathrm{KCl}$ and $40 \mathrm{mM} \beta$-mercaptoethanol. $C y c^{-}$reconstituting activity was then assayed by adding $10 \mu \mathrm{l}$ of the diluted, warmed cholate extracts to $10 \mu \mathrm{l}$ of $c y c^{-}$-membrane suspension (25-35 $\mu \mathrm{g}$ in $1 \mathrm{mM}$ dithiothreitol and $25 \mathrm{mM}$ Na-HEPES, $\mathrm{pH} 8.0$ ), keeping this mixture in the cold for 10-30 min, and assaying for GMP-P(NH)Pstimulated $c y c^{-}$adenylyl cyclase activity by further addition of $30 \mu \mathrm{l}$ of assay reagents to give, in a final volume of $50 \mu \mathrm{l}, 0.1 \mathrm{mM}\left[\alpha{ }^{-32} \mathrm{P}\right] \mathrm{ATP}$ (specific activity $2,000 \mathrm{cpm} / \mathrm{pmol}$ ), $10 \mathrm{mM} \mathrm{MgCl}, 1.0 \mathrm{mM}\left[{ }^{3} \mathrm{H}\right] \mathrm{cAMP}$ ( $\sim 10,000 \mathrm{cpm} /$ assay), $1.0 \mathrm{mM}$ EDTA, the ATP-regenerating system described above for adenylyl cyclase assays, $25 \mathrm{mM}$ Tris- $\mathrm{HCl}$, and 100 $\mu \mathrm{M}$ GMP-P(NH)P. The mixtures were incubated for $40 \mathrm{~min}$ at $30^{\circ} \mathrm{C}$, stopped, and analyzed for $\left[{ }^{32} \mathrm{P}\right] \mathrm{cAMP}$ formed as described (19).

Reconstitution of cyc ${ }^{-}$isoproterenol plus GTP-stimulated activity. Cholate extracts were diluted as above at least fivefold in dilution medium. Aliquots $(20 \mu \mathrm{l})$ were then incubated for $10 \mathrm{~min}$ at $30^{\circ} \mathrm{C}$ with $c y c^{-}$membranes (250-350 $\mu \mathrm{g}$ protein) in a final volume of $100 \mu \mathrm{l}$ containing $0.5 \mathrm{mM}$ ATP, $2.0 \mathrm{mM} \mathrm{MgCl} 2,1 \mathrm{mM}$ EDTA, the ATP-regenerating system described above, and $0.1 \mathrm{mM} \mathrm{GTP}$. This phase of the 
procedure is the reconstitution proper. $10-\mu$ aliquots of the reconstituted mixtures were then transferred to tubes having $30 \mu$ l of a mixture containing $16.7 \mathrm{mM} \mathrm{MgCl}_{2}, 1.67 \mathrm{mM}$ EDTA, $\left.1.67 \mathrm{mM} \mathrm{[}{ }^{3} \mathrm{H}\right] \mathrm{cAMP}$ $(\sim 10,000 \mathrm{cpm})$, the above described ATP-regenerating system, 41.7 $\mathrm{mM}$ Tris- $\mathrm{HCl}, \mathrm{pH} \mathrm{7.5}$, and $16.7 \mu \mathrm{M}$ 1-isoproterenol. After $30 \mathrm{~min}$ at $30^{\circ} \mathrm{C}$, the reconstituted isoproterenol plus GTP-stimulated activity was monitored by postaddition of $10 \times 10^{6} \mathrm{cpm}$ of high specific activity [ $\alpha$ $\left.{ }^{32} \mathrm{P}\right] \mathrm{ATP}$ contained in $10 \mu \mathrm{l}$. The reactions (final concentration of ATP was $0.1 \mathrm{mM}$ and of $\mathrm{MgCl}_{2}$ was $10 \mathrm{mM}$ ) were stopped after 10 min and the $\left.{ }^{32} \mathrm{P}\right]$ cAMP formed was quantitated as described.

By using these assay conditions and at the dilutions of cholate extract employed, the $c y c^{-}$-reconstituted activities were proportional to the microgram quantities of cholate extract protein added. The results of these reconstitution assays are expressed as $c y c^{-}$-reconstituted activities in picomoles of cAMP formed per 40-min assay in the case of reconstitution of GMP-P(NH)P-stimulated activities, or as picomoles of cAMP formed per 10-min assay in the case of reconstitution of isoproterenol plus GTPstimulated activities. In some instances, these activities were corrected for by dividing the above result by the milligram quantity of cholate extract protein added, and thereby yielding specific activities of $c y c^{-}$reconstituting activities which are expressed as nanomoles of cAMP formed per 40- or 10-min assays per milligram of cholate extract protein.

\section{Variability of results}

The activity values obtained for a given membrane cholate extract were reproducible from day to day within $10 \%$ limits. Replicates within a given assay agreed within $5 \%$. As prepared, cholate extracts could be stored at $-80^{\circ} \mathrm{C}$ without loss of activity for up to $4 \mathrm{mo}$, the longest time tested.

Although cholate extracts from different control liver membrane batches gave very similar $\mathrm{cyc}^{-}$-reconstituting activities (as tested in a single assay), the absolute values of $c y c^{-}$-reconstituted activities obtained (i.e., picomoles of cAMP formed under the assay conditions) varied by as much as fivefold depending on the batch of $c y c^{-}$membranes used. This is owing to the fact that reconstituted activities depend on the quality of the $c y c^{-}$adenylyl cyclase system used to assay for regulatory component. In spite of these variations which relate to variability in the growth rate of cells and the cell density at the time of harvest, reconstituted activities were always proportional to micrograms of cholate extract protein added. Thus, the $c y c^{-}$membranes used provided linear assays of reconstituting activity. For these reasons, all studies in which regulatory component activities from various liver membrane preparations are compared were measured in single experiments using a single batch of $c y c^{-}$membranes. Protein was determined by the method of Lowry et al. (24).

\section{Results}

Effects of uremia. The impact of chronic uremia on glucagonstimulable adenylyl cyclase in liver was assessed in membrane preparations of rats made chronically uremic by surgical techniques described previously $(13,14)$. Although basal adenylyl cyclase was not different in uremic as compared with control membranes $(9.9 \pm 0.9,10.3 \pm 2.8 \mathrm{pmol}$ cAMP formed/min per mg membrane protein, respectively; $\mathrm{x} \pm \mathrm{SD}, n=6$ ), glucagonstimulable activity was decreased $27 \%$ in uremia $(53.2 \pm 4.5$, $39.1 \pm 6.1 ; P<0.05$ ) (Table I). No significant effect on the concentration of glucagon required for half-maximal stimulation
Table I. Adenylyl Cyclase Activities of Liver Membranes from Control and Uremic Rats

\begin{tabular}{|c|c|c|}
\hline \multirow[b]{2}{*}{ Additions to assays } & \multicolumn{2}{|c|}{ Adenylyl cyclase activity } \\
\hline & Control & Uremic \\
\hline & \multicolumn{2}{|c|}{$\begin{array}{c}\text { pmol cAMP formed/min per mg } \\
\text { membrane protein }\end{array}$} \\
\hline None & $10.3 \pm 2.8$ & $9.9 \pm 0.9$ \\
\hline GTP & $32.0 \pm 4.6$ & $33.2 \pm 3.7$ \\
\hline GMP-P(NH)P & $75.6 \pm 9.5$ & $78.9 \pm 8.4$ \\
\hline Glucagon & $53.2 \pm 4.5$ & $39.1 \pm 6.1^{*}$ \\
\hline Glucagon + GTP & $186.0 \pm 13.5$ & $160.6 \pm 13.9^{*}$ \\
\hline Glucagon + GMP-P(NH)P & $249.4 \pm 15.0$ & $207.8 \pm 5.4^{*}$ \\
\hline $\mathrm{NaF}$ & $226.5 \pm 27.6$ & $183.8 \pm 11.8^{*}$ \\
\hline $\mathrm{MnCl}_{2}$ & $36.4 \pm 3.2$ & $29.9 \pm 4.3$ \\
\hline
\end{tabular}

Membranes were incubated and adenylyl cyclase activity determined as described under Methods in the absence and presence of $10 \mu \mathrm{M}$ GTP, $10 \mu \mathrm{M}$ GMP-P(NH)P, $10 \mathrm{mM} \mathrm{NaF}, 10 \mathrm{mM} \mathrm{MnCl}$, and $1 \mu \mathrm{M}$ glucagon separately or in combination as indicated. If $\mathbf{M n C l}_{2}$ was added, $\mathrm{MgCl}_{2}$ was omitted. Membranes were incubated for $10 \mathrm{~min}$ at $32.5^{\circ} \mathrm{C}$ as described more completely in Methods. Values shown are the mean \pm SD of at least six experiments.

$* P<0.05$

was noted in uremic as compared with control rats (Fig. 1). The stimulations by saturating glucagon in the presence of GTP and GMP-P(NH)P were reduced by 14 and $17 \%$, respectively $(P<0.05)$ (Table I). Although the NaF-stimulated activity was reduced 19\% $(P<0.05)$, GTP, GMP-P(NH)P, and $\mathrm{MnCl}_{2}$ ac-

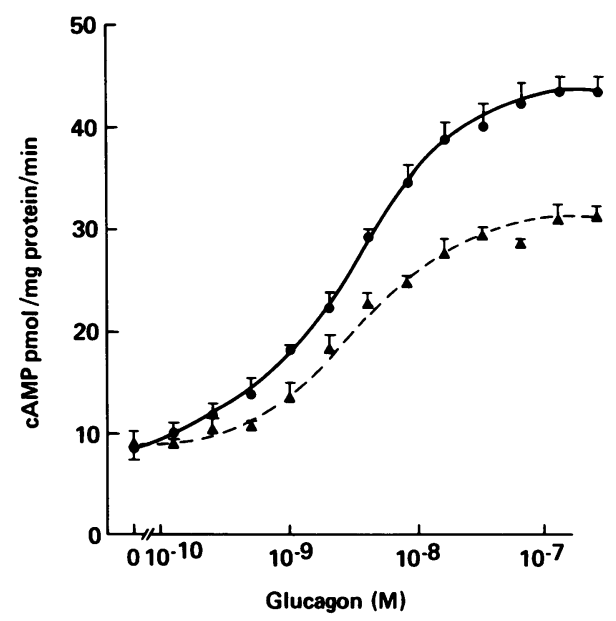

Figure 1. Concentration-effect curves for glucagon stimulation of adenylyl cyclase activity in liver membranes from control $(-\bullet-)$ and uremic (- - $\triangle---)$ rats. Activities were assayed for $10 \mathrm{~min}$ at the indicated concentrations of glucagon using, per assay, 5.2 and $7.3 \mu \mathrm{g}$ of liver membrane protein from control and uremic rats, respectively. For the rest of the conditions, see Methods. 
tivities were not different in uremic as compared with control preparations.

The activity of the guanine nucleotide-binding $\alpha$-subunit of regulatory component was next examined in control and uremic rats by using two methods of assessment. First, a reconstitution of GMP-P(NH)P-stimulable adenylyl cyclase activity in membranes of $\mathrm{S} 49 c y c^{-}$lymphoma cell membranes was performed by using regulatory component activity extracted from rat liver membranes with cholate. Second, the ability of added regulatory component extracted from liver membranes to confer, in the presence of GTP, isoproterenol stimulation to adenylyl cyclase in $\mathrm{S} 49 \mathrm{cyc}^{-}$cell membranes was assessed. The optimal conditions required for these reconstitution assays were investigated and validated. These studies indicated that reconstitution of GMP$\mathrm{P}(\mathrm{NH}) \mathrm{P}$-stimulated $c y c^{-}$adenylyl cyclase activity was best observed in the presence of $20 \mathrm{mM} \beta$-mercaptoethanol and 0.75 $\mathrm{M} \mathrm{KCl}$, which both reduced the lag in appearance in reconstituted activity and led to a constant accumulation of cAMP for 60-80 min. Assays were performed routinely for $40 \mathrm{~min}$. Optimal extraction of reconstituting activity from hepatic membranes was obtained in the presence of $1 \%$ cholate, $1 \mathrm{mM}$ EDTA, and $10 \mathrm{mM} \mathrm{MgCl}$ followed by chelation of excess $\mathrm{MgCl}$ by postaddition of $11 \mathrm{mM}$ EDTA. Coextracted cyclizing activity was inactivated by heating without major loss $(10 \%)$ of the reconstituting activity. Optimal reconstitution of isoproterenol plus GTP-stimulated activities required cholate concentrations to be $<0.1 \%$ during the first reconstitution phase of assay. The reconstituted adenylyl cyclase activity was augmented by $\mathrm{KCl}$ addition in the presence of low but not high cholate concentrations. The dependency on time of the reconstitution of isoproterenol-stimulable adenylyl cyclase activity and $\mathrm{S} 49 \mathrm{cyc} \mathrm{c}^{-}$cell membranes was such that hormonal reconstitution incubations were carried out for $10 \mathrm{~min}$ rather than $40 \mathrm{~min}$. Under these conditions, the reconstitution of the hormonally sensitive adenylyl cyclase activity was linearly dependent on the quantity of regulatory component (cholate extract added) provided the quantity of liver membrane-derived protein in the cholate extract added to the reconstitution assays was $<1 \mu \mathrm{g}$.

We investigated the efficiency with which regulatory component was extracted from liver membranes using the procedures described above. Nielsen et al. (25) have shown that, in $c y c^{-}$ cell membranes, reconstitution of GMP-P(NH)P-stimulated activation of adenylyl cyclase occurs not only with fully solubilized regulatory component, but also with partially solubilized component such as would be present in an adsorbed form on membranes treated with $1 \%$ cholate. We, therefore, measured "total reconstituting activity" by mixing the membrane-cholate mixtures with $c y c^{-}$membranes and assessing the resulting GMP$\mathbf{P}(\mathrm{NH}) \mathrm{P}$-stimulated activity, which reflects totally reconstituted $c y c^{-}$activity, undisturbed liver membrane activity, and some as yet undefined effect of liver membrane-bound regulatory component on $c y c^{-}$membrane-bound adenylyl cyclase. We found that before warming, cholate extracts contained $\sim 75 \%$ of the "maximally" measurable regulatory component activity (not shown). Based on these preliminary studies, it is apparent that $(a)$ the bulk of the regulatory component activity can be extracted from liver membranes, $(b)$ the extracts obtained can be warmed to inactivate endogenous catalytic activity without substantial loss of regulatory component activity, and (c) reconstituted activities can be used to quantitate regulatory component activity, provided that the cholate is diluted sufficiently and that both $\mathrm{KCl}$ and $\beta$-mercaptoethanol are added to accelerate the reconstitution process.

Using these techniques, regulatory component activity was determined in liver membrane preparations of uremic and control rats. Both the "extractability" and $c y c^{-}$-reconstituting activity of regulatory component activity, as assessed by reconstitution of GMP-P(NH)P-stimulable adenylyl cyclase activity, were not different in membranes of uremic as compared with control rats (Table II). Similarly, the capacity of regulatory component from membranes of uremic rats to reconstitute $c y c^{-}$isoproterenol plus GTP-stimulated activity was also unchanged when compared with controls. Thus, using these two assessments of regulatory component activity, the activity of this coupling protein in uremic membranes was found to be unaltered as compared with membranes from control animals.

Because the foregoing data suggest potential alterations of

Table II. Regulatory Component Activities in Liver Membranes from Control and Uremic Rats

\begin{tabular}{lll}
\hline \multirow{2}{*}{ Membranes } & \multicolumn{2}{c}{ Cyc-reconstituting activities in cholate extracts* } \\
\cline { 2 - 3 } & GMP-P(NH)P & Iso plus GTP \\
\hline & $\begin{array}{l}n m o l \text { cAMP formed/40 min/ } \\
\text { mg cholate extract protein }\end{array}$ & $\begin{array}{l}\text { nmol cAMP formed/10 min/ } \\
\text { mg cholate extract protein }\end{array}$ \\
Control & $13.9 \pm 0.3(n=6)$ & $1.03 \pm 0.11(n=6)$ \\
Uremic & $14.5 \pm 0.8(n=6)$ & $1.08 \pm 0.15(n=6)$ \\
\hline
\end{tabular}

Liver membranes from control and uremic rats $(5-7 \mathrm{mg}$ protein $/ \mathrm{ml})$ were extracted as described under Methods, yielding cholate extracts of 2.5-3.1 mg protein $/ \mathrm{ml}$. Each of the extracts was then assayed in duplicate at three different dilutions with $c y c^{-}$membranes for reconstitution of GMP-P(NH)P-stimulated and isoproterenol plus GTPstimulated activities. Final dilutions of cholate extracts during the reconstitution phases of incubations were 250,500 , and 1000 when GMP-P(NH)P-stimulated activities were reconstituted and 50, 100, and 200 when isoproterenol plus GTP activities were reconstituted. This corresponded to input cholate extract proteins of $0.5-0.62 \mu \mathrm{g} /$ $32.5 \mu \mathrm{g} \mathrm{cyc} \mathrm{C}^{-}$membrane protein at the lowest dilution tested and assured proportionality in the assay. Specific activities for reconstituting $c y c^{-}$adenylyl cyclase activities were then calculated, confirmed to be independent of sample dilution under the assay conditions used, and averaged to give the values reported in the table. For the rest of the conditions, see Methods.

* In all final adenylyl cyclase assay stages of incubations, $c y c^{-}$membrane protein was $32.5 \mu \mathrm{g}$. Cyclic AMP due to $c y c^{-}$membranes alone was $0.1 \mathrm{pmol} / 40 \mathrm{~min}$ per assay. 
glucagon receptor function in liver membranes of uremic rats, the number of glucagon receptors and their affinity were examined using monoiodinated glucagon. Binding studies with this highly purified $\left[{ }^{125} \mathrm{I}\right]$ iodoglucagon were performed in hepatic membrane preparations from control and uremic rats, and the data were analyzed by the method of Scatchard (23). The data obtained (Fig. 2) indicate the existence in liver membranes of an apparently single population of high affinity binding sites for the probe. No differences in receptor affinity for this radiolabeled ligand could be detected in membranes of uremic as compared with control animals (Table III). However, the quantity of specific [ $\left.{ }^{125} \mathrm{I}\right]$ iodoglucagon-binding sites was reduced from $5.77 \pm 0.18$ to $4.13 \pm 0.18 \mathrm{pmol}$ of glucagon bound $/ \mathrm{mg}$ membrane protein $(P<0.001 ; n=6)$.

Effect of glucagon administration. It has been suggested that the hyperglucagonemia of chronic renal failure may alter glucagon-responsive adenylyl cyclase activity (9-11). For this reason, potential effects of intermittent glucagon injections on glucagonsensitive adenylyl cyclase in rat liver were investigated. Liver membranes were prepared from rats administered 80-100 $\mu \mathrm{g}$ glucagon (subcutaneous) at 8-h intervals for $3 \mathrm{~d}$; the properties of their adenylyl cyclase system were compared with those in control liver membranes prepared in parallel. As shown in Tables IV-VI and Figs. 3 and 4, glucagon administration reproduced both qualitatively and quantitatively the results obtained in liver membranes of uremic rats: glucagon and sodium fluoride ac-

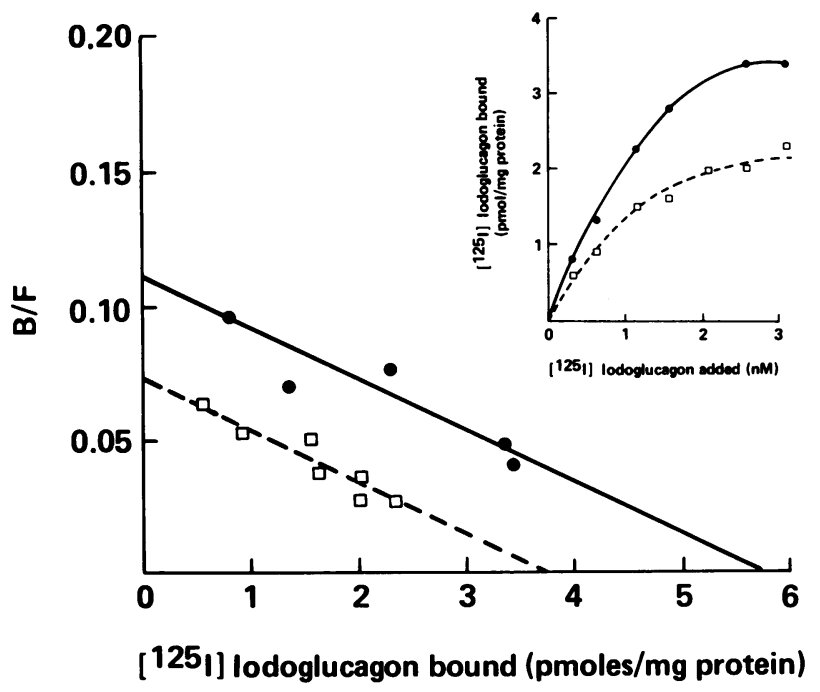

Figure 2. Scatchard analysis of $\left[{ }^{125} \mathrm{I}\right]$ iodoglucagon binding to liver membranes of control and uremic animals. [' $\left.{ }^{125} \mathrm{I}\right]$ Iodoglucagon binding was determined as described under Methods. The values of free and specifically bound $\left[{ }^{125} 1\right]$ iodoglucagon obtained were plotted according to Scatchard (23). The inset shows the saturation curves from which the Scatchard lines for normal $(-\bullet-)$ and uremic $(---\square---)$ membranes were derived. Each point on the saturation curve represents the mean of three determinations. $B / F$, bound/free.
Table III. Glucagon Receptor Density and Affinity in Liver Membranes of Control and Uremic Rats

\begin{tabular}{lll}
\hline $\begin{array}{l}\text { Animal } \\
\text { state }\end{array}$ & $K_{\mathrm{D}}$ & $B_{\max }$ \\
\hline & $n M$ & $p m o l / m g$ \\
Control & 1.85 & $5.77 \pm 0.18$ \\
& $(1.26-3.46)$ & \\
Uremia & 1.87 & $4.13 \pm 0.18^{*}$ \\
& $(1.31-3.27)$ & \\
\hline
\end{tabular}

Liver membranes from control and uremic rats were prepared and incubated as described in Methods. The number and affinity of specific $\left[{ }^{125} \mathrm{I}-\mathrm{Tyr}{ }^{10}\right]$ monoiodoglucagon-binding sites were calculated by means of Scatchard analysis of saturation curves of purified monoiodoglucagon, as shown in Fig. 2. Receptor density values $\left(B_{\max }\right)$ are the mean $\pm \operatorname{SE}(n=6)$; $95 \%$ confidence levels for the $K_{\mathrm{D}}$ values are given in parentheses.

${ }^{*} P<0.001$ compared with control.

tivities of adenylyl cyclase were reduced, but basal, GTP-, GMP$\mathrm{P}(\mathrm{NH}) \mathrm{P}$-, and manganese-dependent activities were unchanged; the $\alpha$-subunit activity of the stimulatory regulatory component was unaltered; and glucagon receptor levels but not affinity were reduced.

Table IV. Adenylyl Cyclase Activities of Liver Membranes from Control and Glucagon-treated Rats

\begin{tabular}{lcc}
\hline & \multicolumn{2}{c}{ Adenylyl cyclase activities } \\
\cline { 2 - 3 } Additions to assays & Control & $\begin{array}{l}\text { Glucagon- } \\
\text { treated }\end{array}$ \\
\hline & $\begin{array}{l}\text { pmol cAMP/ } \\
\text { min per } m g\end{array}$ & $\begin{array}{l}\text { pmol cAMP/ } \\
\text { min per } m g\end{array}$ \\
None & $8.1 \pm 1.4$ & $7.5 \pm 0.4$ \\
GTP & $25.5 \pm 2.0$ & $28.8 \pm 4.8$ \\
GMP-P(NH)P & $74.7 \pm 5.6$ & $72.4 \pm 8.2$ \\
Glucagon & $59.3 \pm 2.9$ & $46.2 \pm 3.5^{*}$ \\
Glucagon + GTP & $148.8 \pm 7.5$ & $119.4 \pm 1.8^{*}$ \\
Glucagon + GMP-P(NH)P & $200.5 \pm 9.6$ & $159.6 \pm 3.8^{*}$ \\
NaF & $181.8 \pm 11.6$ & $147.4 \pm 4.5^{*}$ \\
MnCl $_{2}$ & $29.4 \pm 1.3$ & $28.9 \pm 1.6$ \\
\hline
\end{tabular}

Adenylyl cyclase activity was determined in membranes obtained from control rats and rats injected with $80 \mu \mathrm{g}$ glucagon subcutaneously every $8 \mathrm{~h}$ for $3 \mathrm{~d}$ and sacrificed $3 \mathrm{~h}$ after the final injection. As described in Methods, membranes were incubated for $10 \mathrm{~min}$ at $32.5^{\circ} \mathrm{C}$ in the absence and presence of $1 \mu \mathrm{M}$ glucagon, $10 \mu \mathrm{M} \mathrm{GTP}$, $10 \mu \mathrm{M}$ GMP-P(NH)P, $10 \mathrm{mM} \mathrm{NaF}$, or $10 \mathrm{mM} \mathrm{MnCl}$ separately or in combination as indicated. If $\mathrm{MnCl}_{2}$ was added, $\mathrm{MgCl}_{2}$ was omitted. Values shown are the mean $\pm \mathrm{SD}$ of at least three experiments. $* P<0.05$. 
Table V. Regulatory Component Activities in Liver Membranes from Control and Glucagon-treated Rats

\begin{tabular}{|c|c|c|}
\hline \multirow[b]{2}{*}{ Membranes } & \multicolumn{2}{|c|}{$C y c^{-}$-reconstituting activities in cholate extracts* } \\
\hline & GMP-P(NH)P & Iso plus GTP \\
\hline & nmol cAMP formed/40 $\mathrm{min}$ & nmol cAMP formed/10 min \\
\hline & $\overline{m g \text { cholate extracts protein }}$ & mg cholate extracts protein \\
\hline Control & $10.4 \pm 0.9(n=12)$ & $0.65 \pm 0.04(n=9)$ \\
\hline Glucagon-treated‡ & $10.5 \pm 0.4(n=6)$ & $0.66 \pm 0.05(n=6)$ \\
\hline
\end{tabular}

Liver membranes from control and glucagon-treated rats $(5-7 \mathrm{mg}$ protein/ml) were extracted as described under Methods yielding cholate extracts of 2.6-2.9 mg protein/ml. Each of the extracts was then assayed in triplicate (controls) or duplicate (glucagon-treated) at three different dilutions for reconstitution of GMP-P(NH)P-stimulated and isoproterenol plus GTP-stimulated $c y c^{-}$adenylyl cyclase activities. Specific activities for reconstitution of $c y c^{-}$adenylyl cyclase were calculated, confirmed to be independent of sample dilution, and averaged to give the values reported in the table. For further details, see Methods.

* In all final assay stages of incubations, $c y c^{-}$membrane protein was $27.8 \mu \mathrm{g}$ and cAMP formed due to $c y c^{-}$membranes alone was subtracted from conversions obtained in the presence of cholate extracts prior to calculation of specific reconstituting activities.

₹ Animals were treated with $80 \mu \mathrm{g}$ glucagon subcutaneously every 8 $\mathrm{h}$ for $\mathbf{3} \mathrm{d}$ and killed $\mathbf{3} \mathrm{h}$ after the last injection.

\section{Discussion}

Altered glucagon stimulation of liver adenylyl cyclase in uremia. Disparate conclusions regarding hepatic glucagon-sensitive adenylyl cyclase activity in chronic uremia have been reached (9-

Table VI. Glucagon Receptor Density and Affinity in Liver Membrane of Control and Glucagon-injected Rats

\begin{tabular}{lll}
\hline Animal state & $K_{\mathrm{D}}$ & $B_{\text {max }}$ \\
\hline \multirow{3}{*}{ Control } & $n M$ & $p m o l / m g$ \\
& 1.83 & $5.77 \pm 0.18$ \\
Glucagon-injected & $(1.45-2.59)$ & \\
& 2.10 & $4.04 \pm 0.12^{*}$ \\
& $(1.78-2.62)$ &
\end{tabular}

Liver membranes were prepared from control animals and animals injected with $80 \mu \mathrm{g}$ glucagon thrice daily for $3 \mathrm{~d}$. The membranes were incubated as described in Methods and Scatchard analysis was performed for both types of membranes on saturation curves of $\left[{ }^{125} 1\right]$ iodoglucagon. Calculated receptor affinities and densities are given below. $B_{\max }$ values are the means \pm SE for at least three separate experiments; $95 \%$ confidence limits provided for the $K_{\mathrm{D}}$ values are given in parentheses.

$* P<0.001$ compared with control.

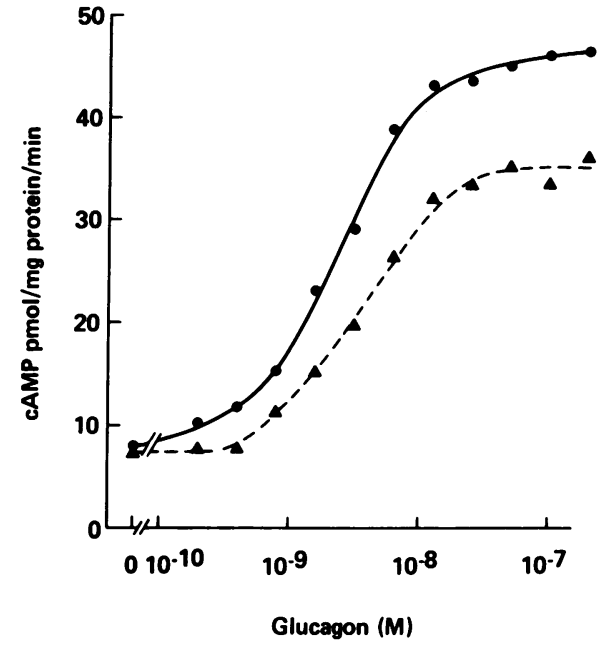

Figure 3. Effect of treatment of rats with glucagon on responsiveness of liver membrane adenylyl cyclase to glucagon. Rats were treated with glucagon ( $100 \mu \mathrm{g} / \mathrm{rat}$, subcutaneous) twice daily for $3 \mathrm{~d}$ and killed $12 \mathrm{~h}$ after the last injection. Liver membranes were prepared

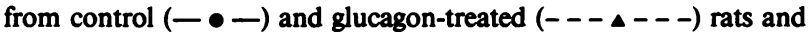
incubated with varying concentrations of glucagon for determination of adenylyl cyclase activities as described under Methods.

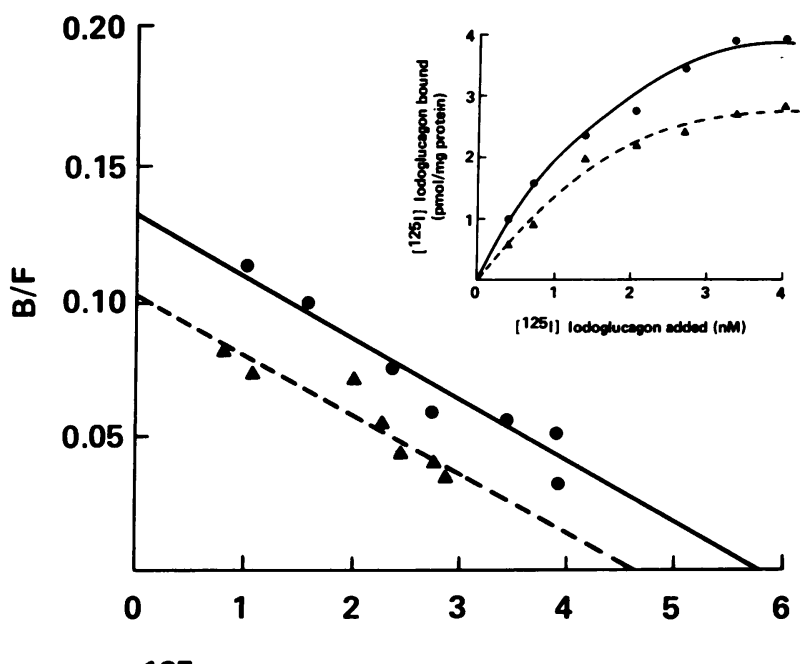

[125|] lodoglucagon bound (pmoles/mg protein)

Figure 4. Scatchard analysis of $\left[{ }^{125} \mathrm{I}\right] \mathrm{iodoglucagon}$ binding to liver

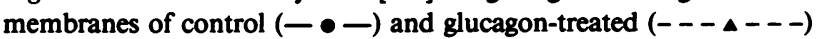
rats. The animals were injected subcutaneously with $80 \mu \mathrm{g}$ glucagon every $8 \mathrm{~h}$ for $3 \mathrm{~d}$ and killed $3 \mathrm{~h}$ after the last injection. Liver membranes were prepared and $\left.{ }^{125} I\right]$ iodoglucagon binding was determined as described under Methods. The values of free and specifically bound [ ${ }^{125}$ I] iodoglucagon obtained were plotted according to Scatchard (23). The inset shows the saturation curve from which values for Scatchard analysis were derived. $B / F$, bound/free. 
11). Although the basis for these discrepant findings is unclear, the results of the present study show clearly that the glucagonstimulable adenylyl cyclase in liver of uremic rats is impaired in a relatively complex manner (Fig. 1, Table I). All forms of glucagon-stimulated activities, both without and with added guanine nucleotides, as well as fluoride-stimulated activity were reduced $20-30 \%$ in uremia. In contrast, basal, manganese-, and guanine nucleotide-stimulated activities per se were unaltered. Glucagon-receptor number but not affinity was decreased in uremia (Fig. 2, Table III). Analysis of the $\alpha$-subunit of the regulatory component activity, as assessed by reconstitution of the S49 $\mathrm{cyc}^{-}$adenylyl cyclase, showed no change. Since the reduction in glucagon-specific binding sites $(\sim 28 \%)$ correlated well with the reduction in glucagon-stimulated adenylyl cyclase $(\sim 27 \%)$, the data strongly suggest that the decrease in glucagon-stimulable adenylyl cyclase activity may be the result of a loss or inactivation of glucagon receptors without significant changes in the remainder of the enzyme complex.

There are three mechanisms which might potentially account for the loss of glucagon-responsive adenylyl cyclase in liver membranes from chronically uremic rats. First, a nonspecific or toxic effect of the uremic state might result in a depressed activity of the enzyme complex. This would appear to be somewhat unlikely since the effect is localized specifically to the number of glucagon-binding sites. Such a change without alterations in receptor affinity, in coupling factors, or in the maximal catalytic capacity of the enzyme would be unexpected, but cannot be entirely excluded. Second, a heterologous desensitization of the glucagon-responsive adenylyl cyclase complex may have been produced as a result of the uremic state. In other tissues, alterations of regulatory component activity or of the kinetics of radioligand binding to the hormone receptor have been observed or suggested as the mechanism accounting for heterologous desensitization (26-28). Marked elevations of parathyroid hormone are a clear concomitant of the chronically uremic state (29-31). Similarly, we have reported elevated levels of catecholamines and a loss of responsiveness of the epinephrine-stimulable adenylyl cyclase in skeletal muscle of chronically uremic rats (32). It is therefore possible that primary alterations in either the epinephrine- or the parathyroid hormone-stimulable adenylyl cyclases or in both may account for the decreased glucagon responsiveness in uremia $(33,34)$. However, this possibility also appears to be somewhat unlikely since, as we show here, primary alterations both of regulatory component activity and in glucagon-receptor affinity are not observed. Finally, chronic uremia is associated with hyperglucagonemia (4-8), and changes in glucagon-stimulated cyclase activity might be the result primarily of the elevated circulating glucagon levels. We, therefore, tested whether or not glucagon administration to rats might mimic in any way the changes in adenylyl cyclase regulation observed in uremia. Glucagon-specific membrane receptors were decreased to a similar extent as in uremia; glucagonand sodium fluoride-stimulated but not basal, GTP-, GMP$\mathrm{P}(\mathrm{NH}) \mathrm{P}$-, or manganese-dependent adenylyl cyclase activities were reduced to an extent similar to that observed in chronic uremia. There were no changes observed in $\alpha$-subunit function of the regulatory component as suggested by reconstitution assays. Taken as a whole, these findings in glucagon-treated animals are entirely consistent with a glucagon-induced desensitization of the glucagon-stimulable adenylyl cyclase in rat liver, the decreased adenylyl cyclase activity in response to glucagon being the result primarily of the decreased glucagon-receptor density following glucagon administration (35-37). Since the data obtained from the glucagon-injected animals are in every way similar to the data obtained on the same hormone-stimulable adenylyl cyclase in liver of uremic rats, it would seem reasonable to conclude that the changes in liver of chronically uremic animals may derive primarily from a glucagon-induced desensitization of the hormone-sensitive adenylyl cyclase complex rather than from a nonspecific toxic effect of the uremic state.

Altered fluoride stimulation of adenylyl cyclase in uremia and glucagon treatment. Decreased sodium fluoride-stimulated adenylyl cyclase activity without concomitant changes in either basal, manganese-dependent, and GTP- or GMP-P(NH)P-stimulated activity was noted in hepatic membranes from both uremic and glucagon-treated as compared with control animals. Such a dissociation between nucleotide-stimulated as compared with fluoride-stimulated activities has not been reported previously. Both sodium fluoride and guanine nucleotides appear to exert their effects by interacting, as do hormone receptors, with the regulatory component (38-42). Detailed studies by Gilman and collaborators (43-46) have shown that the stimulatory regulatory component is formed of at least two distinct subunits: first, an $\alpha$-subunit which is the substrate for ADP ribosylation (47) and which regulates the catalytic activity of adenylyl cyclase per se, and second, a $\beta$-subunit for which no specific function has yet been assigned with certainty. The $c y c$ S49 cell membranes used lack only the $\alpha$-subunit of the regulatory component $(48,49)$, but do contain the $\beta$-subunit. Since activation of regulatory component is dependent on or at least associated with its dissociation into the individual subunits $(50$, 51 ), the reconstitution assay used actually assesses the activated $\alpha$-subunit fraction but not the $\beta$-subunit. Guanine nucleotides exert their action on adenylyl cyclase by interacting with and binding to the $\alpha$-subunit of the regulatory component $(50,51)$. However, while sodium fluoride exerts its action on adenylyl cyclase at the level of the regulatory component (46), the specific subunit at which it interacts is not known, nor is the precise mechanism by which fluoride activates the regulatory component.

The results of the present study show clearly that both guanine nucleotide regulation of adenylyl cyclase, as assessed in the absence of hormone, and the $c y c^{-}$reconstituting activity are unaltered in uremic and glucagon-treated as compared with control liver membranes. These findings strongly indicate that the $\alpha$-subunit of the regulatory component is unaltered. Since sodium fluoride but not nucleotide regulatory activity was decreased in uremic as compared with control liver membranes, 
it is possible that this reflects an alteration either of the level of another subunit or of the capacity of another subunit to interact with the $\alpha$-subunit of the stimulatory regulatory component. This other subunit may be the $\beta$-subunit, or it may well be an as yet undefined factor regulating sodium fluoride but not guanine nucleotide stimulation of cyclic AMP formation. It is of interest that treatment of MDCK cells with glucagon results in a loss of glucagon- and sodium fluoride-stimulated but not basal or guanine nucleotide-regulated adenylyl cyclase activities or in $c y c^{-}$reconstituting activity (52). These findings are essentially identical to the pattern of alterations in adenylyl cyclase activities reported here. Thus, the dissociation between guanine nucleotide and sodium fluoride-stimulated activity observed in this study may not be a phenomenon restricted solely to uremia or to rat liver and may therefore reflect a more common phenomenon of adenylyl cyclase regulation.

\section{Acknowledgments}

This work was supported in part by National Institutes of Health research grants NS15950, RR00350, AM19318, AM-27685, and by grants from the Texas Diabetes Research Foundation and the Fondren Foundation.

\section{References}

1. Rubenfeld, S., and A. J. Garber. 1978. Abnormal carbohydrate metabolism in chronic renal failure. The potential role of accelerated glucose production, increased gluconeogenesis, and impaired glucose disposal. J. Clin. Invest. 62:20-28.

2. Horton, E. S., C. Johnson, and H. E. Lebovitz. 1968. Carbohydrate metabolism in uremia. Ann. Intern. Med. 68:63-64.

3. Lowrie, E. G., J. S. Saeldner, C. L. Hampers, and J. P. Merrill. 1970. Glucose metabolism and insulin secretion in uremic, pre-diabetic and normal subjects. J. Lab. Clin. Med. 76:603-615.

4. Bilbrey, G. L., G. R. Falonna, M. G. White, and J. P. Knochel 1974. Hyperglucagonemia of renal failure. J. Clin. Invest. 53:841-847.

5. Sherwin, R. S., C. Bastl, F. O. Finkelstein, M. Fisher, H. Black, R. Hendler, and P. Felig. 1976. Influence of uremia and hemodialysis on the turnover and metabolic effects of glucagon. J. Clin. Invest. 57:522531.

6. Kuku, S. F., A. Zeidler, D. S. Emmanouel, A. I. Katz, and A. H. Rubenstein. 1976. Heterogeneity of plasma glucagon: patterns in patients with chronic renal failure and diabetes. J. Clin. Endocrinol. Metab. 42:173-176.

7. Emmanouel, D. S., J. B. Jaspan, S. F. Kuku, A. H. Rubenstein, and A. I. Katz. 1976. Pathogenesis and characterization of hyperglucagonemia in the uremic rat. J. Clin. Invest. 58:1266-1272.

8. Valverde, I. 1977. Quantification of plasma glucagon immunoreactive components in normal and hyperglucagonemia states. In Glucagon: Its Role in Physiology and Clinical Medicine. P. O. Foa, J. S. Bajaj, and N. L. Foa, editors. Springer-Verlag, New York. 77-92.

9. Soman, V., and P. Felig. 1977. Glucagon and insulin binding to liver membranes in partially nephrectomized uremic rat model. J. Clin. Invest. 60:224-232.

10. Perez, G. O., A. Rabinovitch, B. Rietberg, B. Owens, and E. R. Schiff. 1982. Impaired glucagon-stimulated glucose output in livers of acutely uremic rats. J. Lab. Clin. Med. 99:669-677.
11. Mondon, C. E., and G. M. Reaven. 1980. Evaluation of enhanced glucagon sensitivity as the cause of glucose intolerance in actively uremic rats. Am. J. Clin. Nutr. 33:1456-1470.

12. Rojas, F. J., T. L. Schwartz, R. Iyengar, A. J. Garber, and L. Birnbaumer. 1983. Monoiodoglucagon: synthesis, purification by high pressure liquid chromatography, and characteristics as a receptor probe. Endocrinology. 113:711-719.

13. Avioli, L. V., S. Scott, S. W. Lee, and H. F. DeLuca. 1969. Intestinal calcium absorption: nature of defect in chronic renal disease. Science (Wash. DC). 166:1154-1155.

14. Russell, J. E., and L. V. Avioli. 1972. Effect of experimental chronic renal insufficiency in bone mineral and collagen maturation. $J$. Clin. Invest. 51:3072-3079.

15. Neville, D. M. 1968. Isolation of an organ specific protein antigen from cell-surface membrane rat liver. Biochim. Biophys. Acta. 154:540552.

16. Pohl, S. L., L. Birnbaumer, and M. Rodbell. 1971. The glucagon sensitive adenylyl cyclase system in plasma membranes of rat liver. $J$. Biol. Chem. 246:1849-1856.

17. Coffino, P., H. R. Bourne, and G. M. Tomkins. 1975. Someic genetic analysis of cyclic AMP action: selection of unresponsive mutants. J. Cell. Physiol. 85:603-610.

18. Ross, E. M., M. E. Maguire, T. W. Sturgill, R. L. Biltonen, and A. G. Gilman. 1977. Relationship between $\beta$-adrenergic receptor and adenylate cyclase. Studies of ligand binding and enzymatic activity in purified membranes of S49 lymphoma cells. J. Biol. Chem. 252:57615775.

19. Salomon, Y., C. Londos, and M. Rodbell. 1974. A highly sensitive adenylate cyclase assay. Anal. Biochem. 58:541-548.

20. Bockaert, J., M. Hunzicker-Dunn, and L. Birnbaumer. 1976. Hormone-stimulated desensitization of hormone-dependent adenylyl cyclase dual action of luteinizing hormone on pig graffian follicle membranes. J. Biol. Chem. 251:2653-2663.

21. Birnbaumer, L., H. N. Torres, M. M. Flawia, and R. F. Fricke. 1979. Improved methods for determination of guanyl cyclase activity and synthesis of ${ }^{32} \mathrm{P}$ GTP. Anal. Biochem. 93:124-133.

22. Iyengar, R., P. W. Mintz, T. L. Swartz, and L. Birnbaumer. 1980. Divalent cation-induced desensitization of glucagon stimulable adenylyl cyclase in rat liver plasma membranes: GTP-dependent stimulation by glucagon. J. Biol. Chem. 255:11875-11882.

23. Scatchard, G. 1949. The attractions of proteins for small molecules and ions. Ann. NY. Acad. Sci. 51:660-672.

24. Lowry, O. H., N. J. Rosebrough, A. L. Farr, and R. J. Randall. 1951. Protein measurement with Folin phenol reagent. J. Biol. Chem. 193:265-275.

25. Neilson, T., P. Ladd, M. S. Preston, and M. Rodbell. 1980. Characteristics of the guanine nucleotide regulatory component of adenylyl cyclase in human red blood cell membranes. Biochim. Biophys. Acta. 629:143-155.

26. Ho, R. J., and E. W. Sutherland. 1977. Formation and release of a hormone antagonist by rat adipocytes. J. Biol. Chem. 246:68226827.

27. Su, Y. F., X. L. Cubeddu, and J. P. Perkins. 1976. Regulation of adenosine 3',5'-monophosphate content in human astrocytoma cells: desensitization to catecholamines and prostaglandins. J. Cyclic Nucleotide Res. 2:351-370.

28. Conti, M., J. P. Harwood, A. J. W. Hsueh, M. L. Dukau, and K. J. Catt. 1967. Gonadotropin-induced loss of hormone receptors and 
desensitization of adenylate cyclase in the ovary. J. Biol. Chem. 251:77297731.

29. Jacob, A. J., D. Lanier, J. Canterbury, and J. J. Bourgoignie. 1980. Reduction by cimetidine of serum parathyroid hormone levels in uremic patients. $N$. Engl. J. Med. 302:671-674.

30. Reiss, E., and J. Canterbury. 1967. A radioimmunoassay for circulating parathyroid hormone in man: preliminary results. $J$. Lab. Clin. Med. 70:1012-1013.

31. Berson, S. A., and R. S. Yalow. 1967. Radioimmunoassay of peptide hormones in plasma. N. Engl. J. Med. 277:640-647.

32. Garber, A. J. 1978. The regulation of skeletal muscle alanine and glutamine formation and release in experimental chronic uremia in the rat. Subsensitivity of adenylate cyclase and amino acid release to epinephrine and serotonin. J. Clin. Invest. 62:633-641.

33. Neuman, W. F., and N. Schneider. 1980. The parathyroid hormone-sensitive adenylate cyclase system in plasma membranes of rat liver. Endocrinology. 107:2082-2087.

34. Pohl, S. L., L. Birnbaumer, and M. Rodbell. 1969. Glucagonsensitive adenyl cyclase in plasma membrane of hepatic parenchymal cells. Science (Wash. DC). 164:566-567.

35. Bockaert, J., M. Hunzicker-Dunn, and L. Birnbaumer. 1976. Hormone-stimulated desensitization of hormone-dependent adenylyl cyclase. J. Biol. Chem. 251:2653-2663.

36. Ezra, E., and Y. Salomon. 1980. Mechanism of desensitization of adenylate cyclase by lutropin. GTP-dependent uncoupling of the receptor. J. Biol. Chem. 255:650-658.

37. Ezra, E., and Y. Salomon. 1981. Mechanism of adenylate cyclase by lutropin. Impaired introduction of GTP into the regulatory site. $J$. Biol. Chem. 256:5377-5382.

38. Rodbell, M., H. M. J. Krans, S. L. Pohl, and L. Birnbaumer. 1971. The glucagon-sensitive adenylyl cyclase system in plasma membranes of rat liver. IV. Effects of guanyl nucleotides on binding of ${ }^{125}$ Iglucagon. J. Biol. Chem. 246:1872-1876.

39. Cassel, D., and Z. Selinger. 1976. Catecholamine-stimulated GTPase activity in turkey erythrocyte membranes. Biochim. Biophys. Acta. 452:538-551.

40. Cassel, D., and Z. Selinger. 1977. Mechanism of adenylate cyclase activation by cholera toxin: inhibition of GTP hydrolysis at the regulatory site. Proc. Natl. Acad. Sci. USA. 74:3307-3311.
41. Pfeuffer, T. 1977. GTP-binding proteins in membranes and the control of adenylate cyclase activity. J. Biol. Chem. 252:7224-7234.

42. Iyengar, R. 1981. Hysteretic activation of adenylyl cyclases. II. $\mathrm{Mg}$ ion regulation of the activation of the regulatory component as seen in reconstitution assays. J. Biol. Chem. 256:11042-11050.

43. Sternweis, P. C., and A. G. Gilman. 1979. Reconstitution of catecholamine-sensitive adenylate cyclase. Reconstitution of the uncoupled variant of S49 lymphoma cell. J. Biol. Chem. 254:3333-3340.

44. Ross, E. M., and A. G. Gilman. 1977. Resolution of some components of adenylate cyclase for catalytic activity. J. Biol. Chem. 252:6966-6969.

45. Ross, E. M., and A. G. Gilman. 1980. Biochemical properties of hormone-sensitive adenylyl cyclase. Annu. Rev. Biochem. 49:533564.

46. Sternweis, P. C., J. K. Northup, E. Hanski, L. S. Scheifer, M. D. Smigel, and A. G. Gilman. 1981. Purification and properties of the regulatory component (G/F) of adenylate cyclase. Adv. Cyclic Nucleotide Res. 14:23-36.

47. Johnson, G. L., H. R. Kaslwo, and H. R. Bourne. 1978. Genetic evidence that cholera toxin substrates are regulatory components of adenylyl cyclase. J. Biol. Chem. 253:7120-7123.

48. Hildebrandt, J. D., R. D. Sekura, J. Codina, R. Iyengar, C. R. Manclark, and L. Birnbaumer. 1983. Stimulation and inhibition of adenylyl cyclases mediated by distinct regulatory proteins. Nature (Lond.). 302:706-709.

49. Manning, D. R., and A. G. Gilman. 1983. The regulatory components of adenylate cyclase and transducin. A family of structurally homologous guanine nucleotide-binding proteins. J. Biol. Chem. 258:7059-7063.

50. Schleifer, L. S., R. A. Kahn, E. Hanski, J. K. Northup, P. C. Sternweis, and A. G. Gilman. 1982. Requirements for cholera toxindependent ADP-ribosylation of the purified regulatory component of adenylate cyclase. J. Biol. Chem. 257:20-23.

51. Bokoch, G. M., T. Katada, J. K. Northup, E. L. Hewlett, and A. G. Gilman. 1983. Identification of the predominant substrate for ADP-ribosylation by islet activating protein. J. Biol. Chem. 258:20722075.

52. Rich, K. A., G. O. Floyd, and R. Iyengar. 1983. Glucagoninduced desensitization of MDCK cell adenylyl cyclase. Endocrinology. 112(Suppl):137. (Abstr.) 